\title{
Hydrogeological and Hydrochemical Assessment of the Quaternary Aquifer South Qena City, Upper Egypt
}

\author{
Ali M. Hamdan ${ }^{1}$ \\ ${ }^{1}$ Geology Department, Faculty of Science, Aswan University, Egypt \\ Correspondence: Ali M. Hamdan, Geology Department, Faculty of Science, Aswan University, Egypt. E-mail: \\ alielaraby1@yahoo.com
}

Received: November 6, 2012 Accepted: December 2, 2012 Online Published: December 31, 2012

doi:10.5539/esr.v2n2p11

URL: http://dx.doi.org/10.5539/esr.v2n2p11

\begin{abstract}
The aim of present work is to study the hydrogeological and hydrochemical assessment of the quaternary aquifer in area south Qena city, Upper Egypt. Quaternary aquifer is the most important source of water, not only in study area, but also in most of desert fringes new reclaimed areas along Nile valley in Egypt. Hydrogeological assessments include study the aquifer system conditions, composition, water level, groundwater flow, depth, recharge, and discharge. The Quaternary aquifer is made up of successive layers of fluvial sands and gravels with minor clay intercalations and it capped with Neonile silt and fine-grained sand in floodplain area, which are replaced by recent sediments in desert fringes. Therefore, the aquifer is under semi-confined condition in the floodplain, but it is under unconfined condition in the desert fringes. All chemical constituents have shown an increase under the desert fringes related to leaching processes of highly soluble minerals, which has high effect in the geochemistry of groundwater in its flow path. The geochemical composition of groundwater indicates direct relation between the lithology and relative abundance of ions. The floodplain area has lower ions concentrations than desert fringes, due to the continuous recharge of fresh water from the Nile River through the irrigation conveying system. The hypothetical salt combination revealed the presence of different salts arranged in terms of their predominant as $\mathrm{NaCl}, \mathrm{Na}_{2} \mathrm{SO}_{4}, \mathrm{NaHCO}_{3}, \mathrm{Mg}\left(\mathrm{HCO}_{3}\right)_{2}, \mathrm{Ca}\left(\mathrm{HCO}_{3}\right)_{2}, \mathrm{MgSO}_{4}$, and $\mathrm{KCL}$. The groundwater qualities were assessed, and the results revealed that all groundwater, at the floodplain and desert fringes areas, are suitable for drinking and irrigation purposes. However, the floodplain water parameters closer to acceptable limits of the WHO, EPA, and EHCW.
\end{abstract}

Keywords: hydrogeology, hydrochemistry, floodplain and desert fringes, Qena, Upper Egypt

\section{Introduction}

The study area is located to the east of the Nile south Qena city; within the transitional zone between the Eastern desert and the Nile valley. It lies between latitudes $26^{\circ} 07^{\prime}-26^{\circ} 11^{\prime} \mathrm{N}$ and longitudes $32^{\circ} 45^{\prime}-33^{\circ} 49^{\prime} \mathrm{E}$ (Figure 1). The average ground elevation varies from about $72 \mathrm{~m}$ above mean sea level in the western part (cultivated area) to about $126 \mathrm{~m}$ a. m. s. 1 . in the eastern part with a gentle slope to the northwest.

It covers a region that includes both the floodplain and the desert fringes which extends to the downstream of the wadis. During the last decade, a strip of the desert fringes has been reclaimed and irrigated completely with groundwater (Figure 2). In a near future, this area considers an important desert area for building new settlements (new Qena city, new industrial areas, etc.) and for new reclamation. These activities will require groundwater with suitable quality for drinking, domestic and agricultural purposes.

Groundwater is an important source of freshwater for agricultural, drinking and domestic uses in many regions of the world (Balachandar et al., 2010). Groundwater assessment for drinking and irrigation has become a necessary and important task for present and future groundwater quality management. Nowadays, many studies have focused on groundwater quality monitoring and evaluation for drinking and agricultural activities around the world (Mitra et al., 2007; Hakim et al., 2009; Selim, 2009; Jain et al., 2010; Nagarajan et al., 2010; Li et al., 2011; Obiefuna et al., 2011).

With the increasing demands for water due to increasing population, urbanization and agricultural expansion, groundwater resources are gaining much attention, particularly in arid and semi-arid regions. So, the current study aimed to evaluate the potentiality of groundwater resources on the study area. 


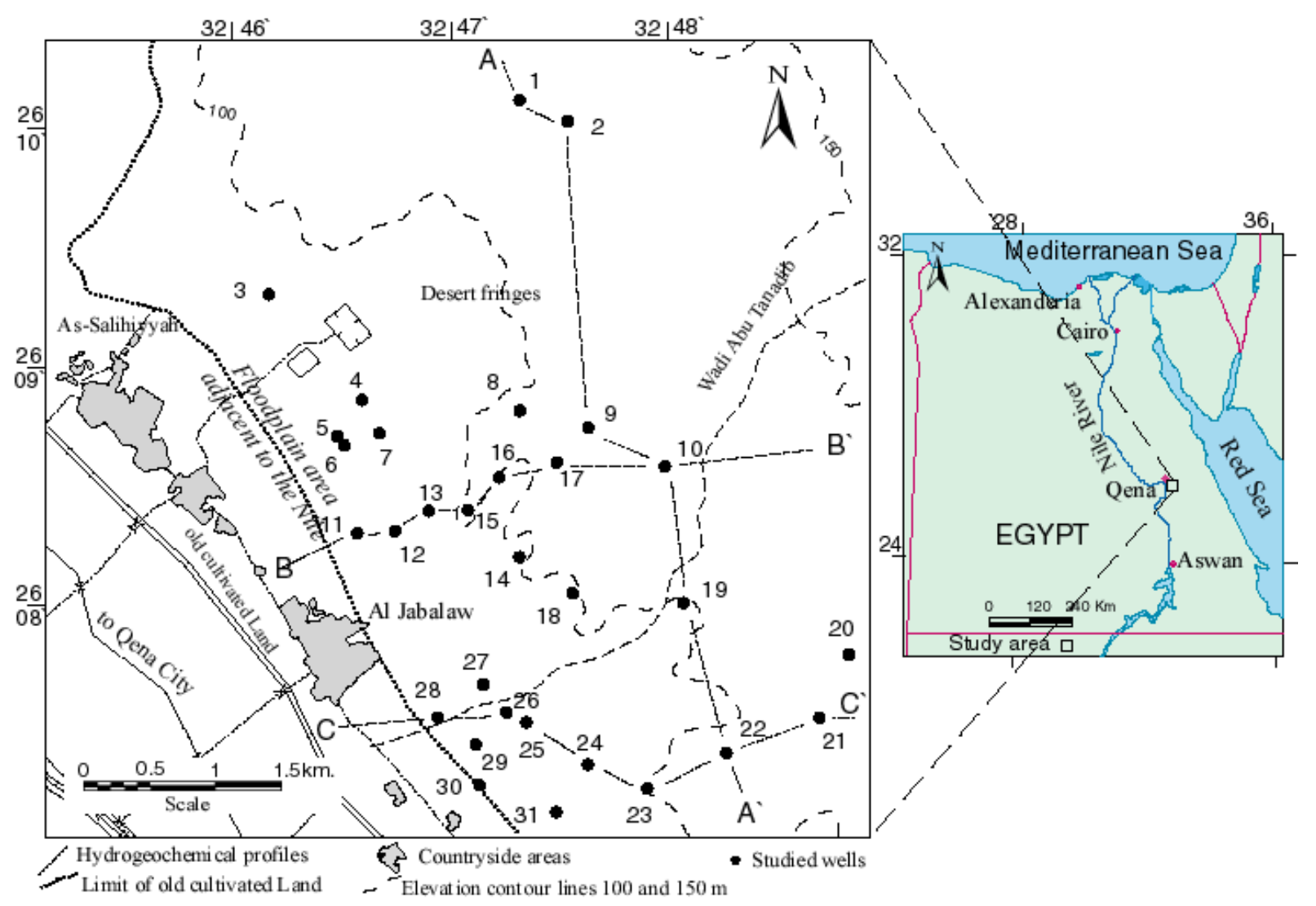

Figure 1. The location and the main landforms of the studied area

The sustainable use of water requires a thorough understanding of the local geology, hydrogeology and hydrgeochemistry. Therefore, the main objective of this work is to study the geology, hydrogeology and to analyze the major constituents of the groundwater from the quaternary aquifer.

The geology and hydrogeological studies include:

- Study the general geology especially for the Quaternary sediments which represent the main aquifer in the study area.

- Assessment of the aquifer types, aquifer system condition, and depth to groundwater.

- Measure the change in water level values and the general groundwater flow.

- Identifying the aquifer recharge and discharge areas.

The hydrochemical studies include:

- Determine the physical and hydrochemical properties of the groundwater.

- Obtain a comprehensive framework of the of groundwater quality (for drinking and agricultural activities) in the studied area.

- Detect hypothetical salt assemblages and groundwater genesis.

\section{Geological Setting}

The study area considers as part of the Nile valley and built up mainly of Quaternary sediments which forming the main aquifer at the study area (Figures 3 and 4). It bounded from the east by Lower Eocene limestone plateau which rises to more than $+450 \mathrm{~m}$. The lithostratigraphic units of the central part of the Eastern Desert are belonging to Upper Cretaceous-Lower Eocene exposures (Abd El Razik, 1972; Said, 1962, 1981, 1990; Sandford, 1934). 


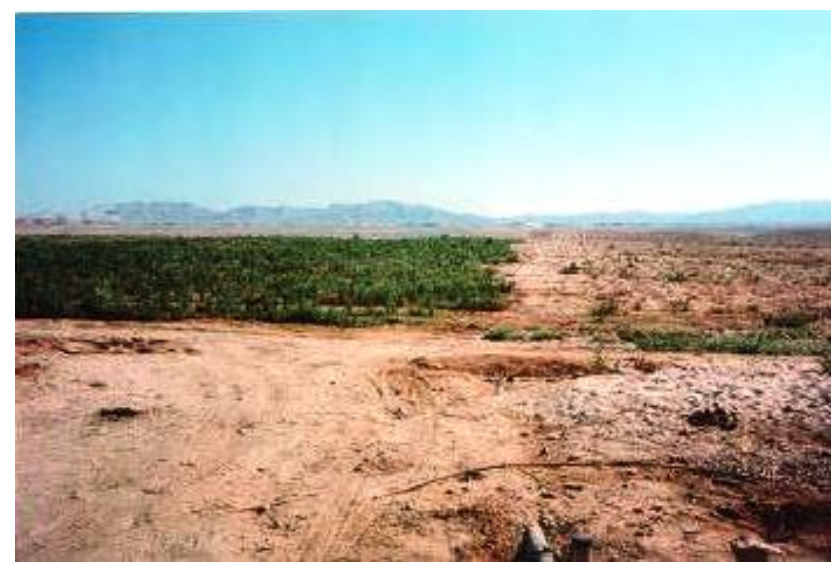

Figure 2. Photographs showing new reclaimed areas at desert fringes

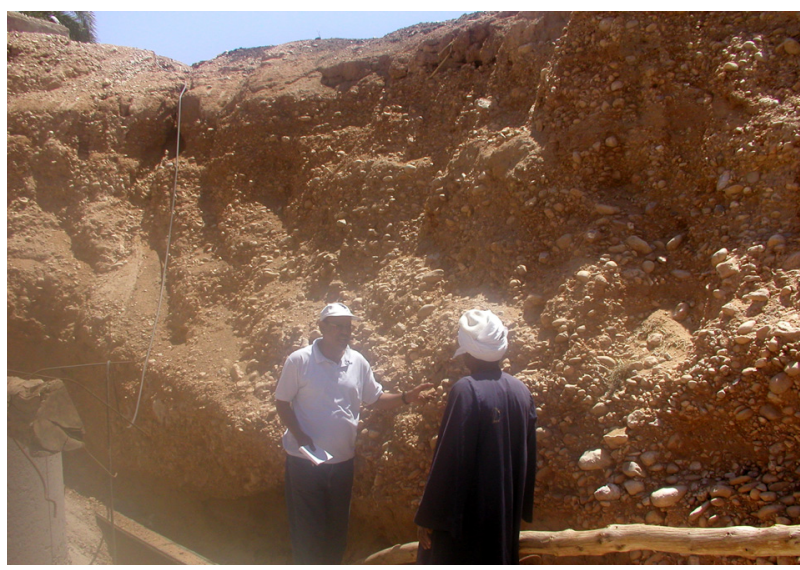

Figure 3. Photographs showing Quaternary sediments at the study area

The Quaternary deposits can be subdivided into the following units according to Said's classification (1981), Figure 4:

i) Recent deposits $(Q w)$ : these deposits comprise unconsolidated sediments represented by wadi filling and sand deposits. It composed of gravels of different sizes in sandy, limy and clayey matrix which is derived from the adjacent limestone plateau. Sand deposits are represented as sand covering most of the slopes of the elevated plateaus.

ii) Neonile sediments (Q3): these deposits are made up of the modern Nile silts and fluvial sands which belong to the Late Pleistocene and the Holocene. They represent the last and extant river (the Neonile) occupying the valley of the Nile that rests over the eroded surface of the Prenile sediments with a marked unconformity.

iii) The Prenile sediments (Q2): they are represent by Qena Formation which is made up of cross bedded fluvial sands and gravel with minor clay beds. It overlies the Late Pliocene sediments (Madamoud Formation). The composite thickness of the formation including the subsurface graded sands and gravel unit exceeds $70 \mathrm{~m}$.

iv) Paleonile/Protonile interval sediments (Tplu/Q1): they deposited over the eroded surface of the Paleonile sediments were divided mainly into two formations (Armant and Issawia formations). The Armant Formation constitutes the early part of the hybrid Paleonile/Protonile interval and made up of conglomeritic deposits that outcrop along the foot slopes of the bounding cliffs of the study area. Its thickness ranges from few meters to more than $40 \mathrm{~m}$. The Isawia Formation follows on top of Armant Formation and made up of massive rubble breccias, marl, clay and travertine.

v) The Paleonile (Tplu), represented by Madamoud Formation: sediments belonging to the Paleonile river system consist of a long series of interbedded red-brown clays and thin fine-grained sand and silt laminae which crop out along the banks of the valley. 


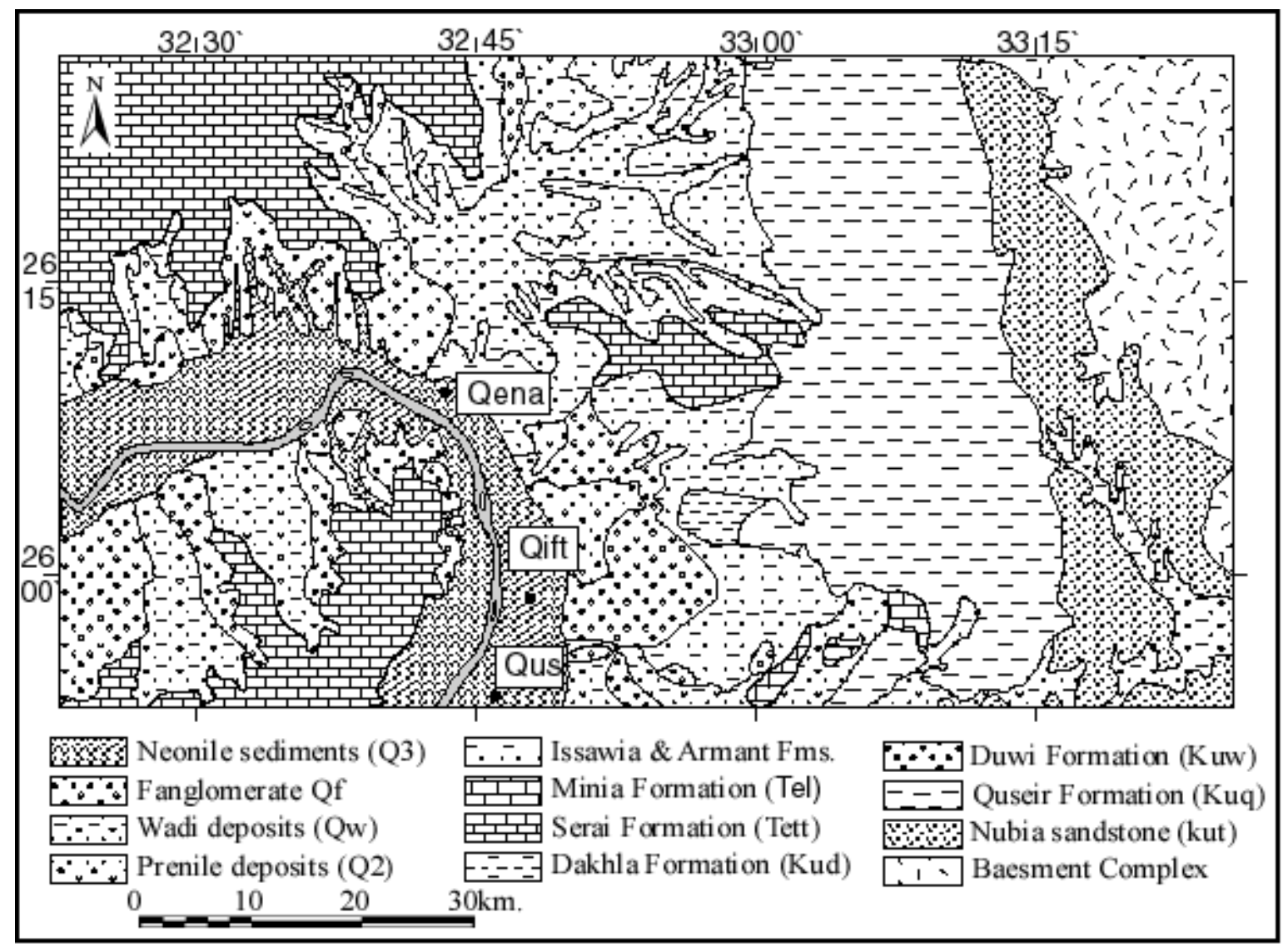

Figure 4. Geological map of the studied area (after CONOCO, 1987)

\section{Materials and Methods}

The present work intends to study the hydrogeochemistry of the Quaternary aquifer of area south Qena City, Upper Egypt. To achieve this, 31 groundwater samples have been collected during May 2010 from different localities along the studied area include both the floodplain and the desert fringes (new reclaimed areas) (Figure $1)$.

The water samples were collected from wells only after sufficient time of pumping to insure that the sample represents the original groundwater source. The suspended particles were separated by filtration. Electric Conductivity (E.C.) and the $\mathrm{pH}$ were measured in the field after collection directly. Well data collected during the field trip (ground elevation, water level and depth) to give a general view for the Quaternary aquifer along the studied area. The collected water samples were subjected to various chemical analysis including the determination of the total dissolved solids (TDS), $\mathrm{pH}$, E.C. and the concentration of $\mathrm{Ca}^{2+}, \mathrm{Mg}^{2+}, \mathrm{Na}^{+}, \mathrm{K}^{+}$cations and $\mathrm{HCO}_{3}{ }^{-}, \mathrm{SO}_{4}{ }^{2-}$, and $\mathrm{Cl}^{-}$anions. Appropriate methods and instruments were used in chemical analyses of the water samples, according with the analyzed parameter.

\section{Hydrogeological Setting}

At the study area, the Quaternary sediments represent the main aquifer in both the floodplain and the desert fringe areas. The Quaternary aquifer sediments are made up of successive layers of fluvial sands and gravels with minor clay intercalations (Prenile, Qena Formation).

In the floodplain area, the Quaternary aquifer is capped with the Neonile silt and fine-grained sand that constitutes the base of the cultivated lands, which is replaced by the recent sediments $(\mathrm{Qw})$ in the desert fringes. Therefore, the aquifer system is under semi-confined condition in the floodplain, but it is under unconfined condition in the desert fringes.

The potentiometric map of the Quaternary aquifer (Figure 5) reflects that the water level values range between 75.5 and $90 \mathrm{~m}$ a. $\mathrm{m}$. s. 1. They decrease in the floodplain area and increase at the desert fringes. The groundwater flow along the study area (Figure 5) is from the desert fringes to the floodplain areas and to the Nile River. The 
depth to groundwater, in the Quaternary aquifer, ranges from 5.0 (at the floodplain area) to $35 \mathrm{~m}$ (at the desert fringes area). The depth to groundwater increase toward the desert fringes area reflecting increase the coast of water extraction for irrigation purposes in that location (reclaimed areas).

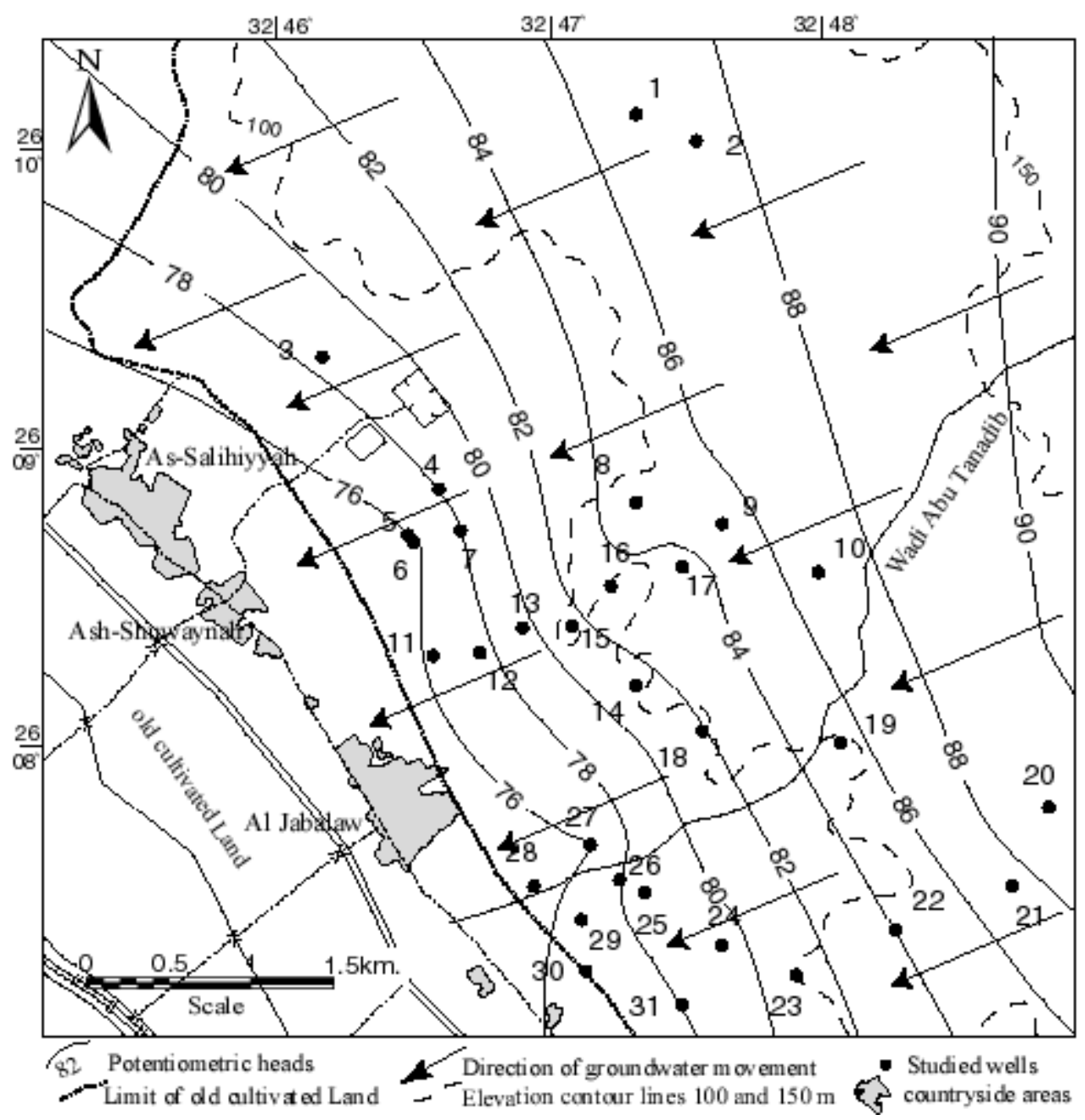

Figure 5. Potentiometric map of the studied area

The recharge to the aquifer is mainly from the irrigation system in the Nile Valley. Secondary source of groundwater recharge is the underflow from rainfalls during winter months each few years. The aquifer discharged by pumping from the drilled wells which are used for irrigation purposes, as well as by seepage to the Nile River. Generally, the relief of the studied area influences to wide extent the flow of the groundwater in the Quaternary aquifer, Rashed et al. (2006).

\section{Hydrogeochemical Assessment}

The collected groundwater samples from the floodplain and the desert fringes (new reclaimed areas) were analyzed to determine the concentration of major ions (Table 1). The results of the chemical analyses were used to understand the various possibilities for water recharge, movement and mixing in the study area.

During this study the permissible limit value of error percentage or ion-balance error $(\mathrm{e} \%)$ is less than $5 \%$ where it vary from 0.07 to $4.94 \%$.

\subsection{Physical Properties of the Groundwater}

The total hardness values are dictated by the amount of $\mathrm{Ca}^{2+}$ and $\mathrm{Mg}^{2+}$ ions (range between 82.8 and $427.4 \mathrm{ppm}$ ) and generally increase toward the desert fringes and decrease toward the floodplain area. The groundwater 
classes are $6 \%$ slightly hard water, $52 \%$ moderately hard water, and $42 \%$ very hard water with predominance of moderately hard at the studied area.

The $\mathrm{pH}$ values range between 6.5 and 7.8, revealing a neutral to alkaline trend (Table 1). Higher values of EC (average of $2072 \mu \mathrm{S} / \mathrm{cm}$ ) are recorded in the groundwater of the desert fringes area indicating a longer residence time and less circulation of the groundwater.

Table 1. Chemical analysis of the groundwater samples in the study area

\begin{tabular}{lcccccc}
\hline \multirow{2}{*}{ Parameters } & & Units & Minimum & Maximum & Mean & Standard deviation \\
\hline \multirow{4}{*}{ Physical parameters } & $\mathrm{pH}$ & ------- & 6.5 & 7.8 & 7.3 & 0.33 \\
& $\mathrm{EC}$ & $\mu \mathrm{S} / \mathrm{cm}$ & 763 & 4693 & 2071 & 914 \\
& $\mathrm{TDS}$ & $\mathrm{mg} / \mathrm{L}$ & 488 & 3004 & 1326 & 585 \\
& $\mathrm{TH}$ & $\mathrm{mg} / \mathrm{L}$ & 85.4 & 427.4 & 203.9 & 75.9 \\
& $\mathrm{SAR}$ & $\mathrm{meq} / \mathrm{L}$ & 5.91 & 19.32 & 10.94 & 4.08 \\
& $\mathrm{e} \%$ & ----- & 0.07 & 4.94 & 3.08 & 1.35 \\
\hline \multirow{4}{*}{ Cations } & $\mathrm{Ca}^{2+}$ & $\mathrm{mg} / \mathrm{L}$ & 16.1 & 74.8 & 33.7 & 12.5 \\
& $\mathrm{Mg}^{2+}$ & $\mathrm{mg} / \mathrm{L}$ & 11.0 & 59.4 & 29.1 & 11.7 \\
& $\mathrm{Na}^{+}$ & $\mathrm{mg} / \mathrm{L}$ & 129.9 & 918.1 & 371.2 & 190 \\
\multirow{4}{*}{ Anions } & $\mathrm{K}^{+}$ & $\mathrm{mg} / \mathrm{L}$ & 6.88 & 55.0 & 12.57 & 8.96 \\
& $\mathrm{HCO}_{3}$ & $\mathrm{mg} / \mathrm{L}$ & 119.6 & 475.8 & 280.0 & 89.6 \\
& $\mathrm{SO}_{4}$ & $\mathrm{mg} / \mathrm{L}$ & 73.4 & 635.1 & 291.3 & 160 \\
& $\mathrm{Cl}^{-}$ & $\mathrm{mg} / \mathrm{L}$ & 74.4 & 929.5 & 307.7 & 202 \\
\hline
\end{tabular}

The TDS values range between 488 and $3004 \mathrm{mg} / \mathrm{l}$, with an average of $2071 \mathrm{mg} / \mathrm{l}$ (Table 1). The Standard deviation of TDS is relatively high (585) reflecting many variations exist between TDS values with some locations have high spreads from the mean and have relatively very low or high TDS values along the area (inhomogeneity distribution).

The distribution map of TDS in the groundwater (Figure 6) shows that the floodplain area and the eastern-central parts characterized relatively by low TDS values. The fresh character of the groundwater of this area may be related to its connection to water of the Nile River directly or through the irrigation system.

The majority of the groundwater at the desert fringes and new reclaimed areas, mainly at south and north areas, show high TDS values. The high salinity values of the Quaternary aquifer, under those areas, may be related with dissolving processes of natural salts present in the host sediments and soil during rains and irrigations, that percolate to the aquifer increasing its salinity. By time with still increase recharge of the concern aquifer by the high TDS water related to the leaching process of sediments and soil, the salinity degree well increase to very high levels, then it can become unsuitable for different purposes, especially drinking or irrigation. So it's strongly recommended to use modern methods for irrigation in those areas.

\subsection{Major Ions Concentration and Distribution}

The hydrochemical properties of groundwater samples collected from the studied area are shown in Table 1. Most samples were from boreholes tapping the Quaternary aquifer at the desert fringes area.

Near the floodplain area, the chemical composition of the groundwater is dominated by Sodium $\left(\mathrm{Na}^{+}\right)$and Bicarbonate $\left(\mathrm{HCO}_{3}{ }^{-}\right)$, while under the desert fringes; $\mathrm{Na}^{+}$and $\mathrm{Cl}^{-}$are dominant. The high concentration of $\mathrm{HCO}_{3}{ }^{-}$indicates the intense chemical weathering processes taking place in this aquifer. Natural processes such as the dissolution of carbonate minerals and of soil $\mathrm{CO}_{2}$ gas could be a mechanism which supplies $\mathrm{HCO}_{3}^{-}$to the groundwater of the Quaternary aquifer. 


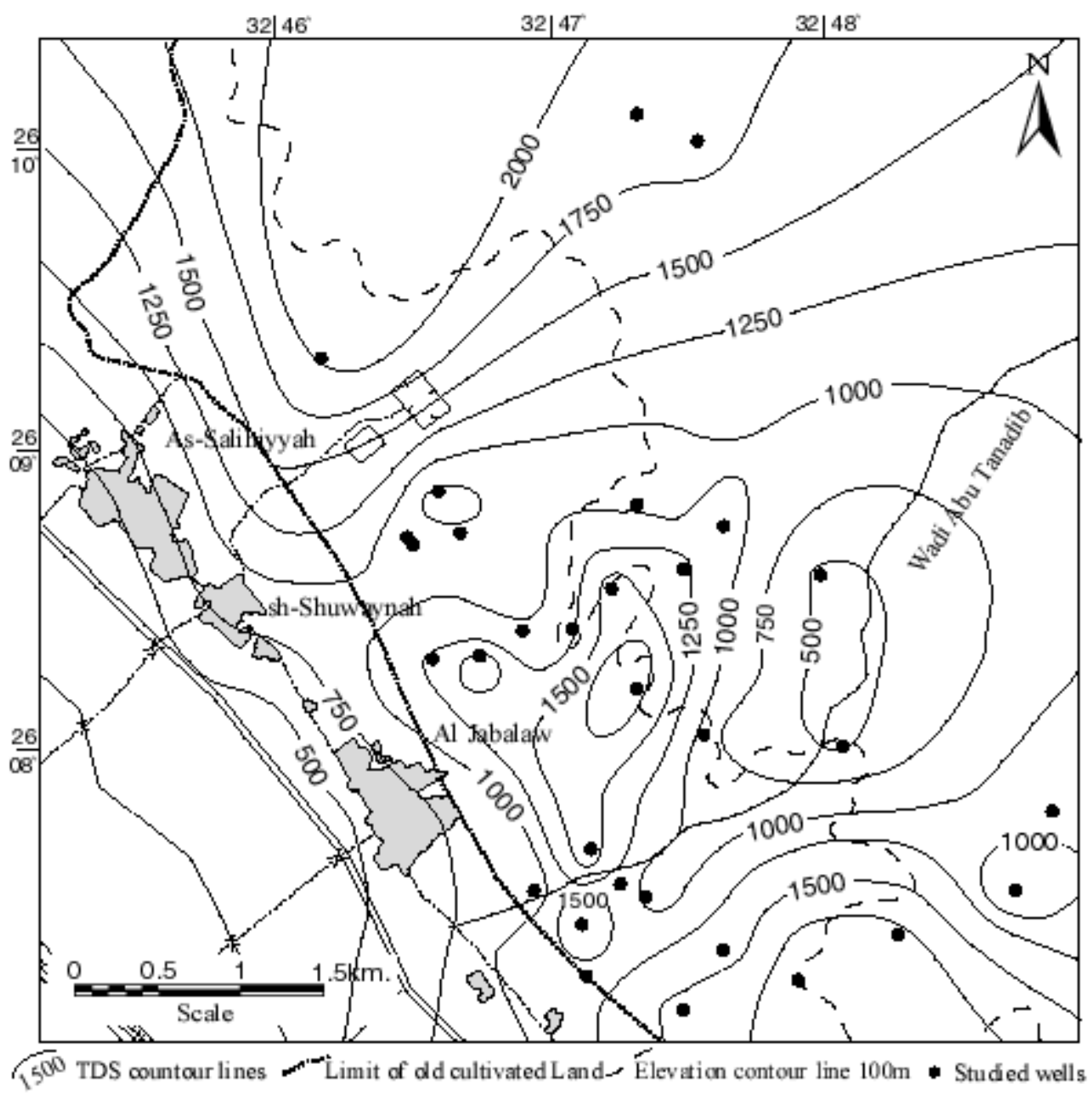

Figure 6. Salinity map of the groundwater at the studied area

Sulphate values $\left(\mathrm{SO}_{4}{ }^{2-}\right.$ ) ranges from 73.4 to $635 \mathrm{ppm}$ (average of $291 \mathrm{mg} / \mathrm{l}$ ). The sources of sulphate include the dissolution of sulphide minerals (gypsum $\mathrm{CaSO}_{4} \cdot 2\left(\mathrm{H}_{2} \mathrm{O}\right)$ and anhydrite $\mathrm{CaSO}_{4}$ ), rainfall and fertilizers. High chloride values (vary from74.4 to $929.5 \mathrm{ppm}$ ) are possibly related to leaching of soluble chloride minerals.

In general, all chemical constituents have shown an increase in their concentrations under the desert fringes may be related to leaching processes of highly soluble minerals, which has high effect in the geochemistry of the groundwater in its flow path. The geochemical composition of groundwater in the studied area indicates a direct relation between the lithology and relative abundance of ions. The groundwater from the desert fringes has high ions concentrations, whereas their concentrations are low in groundwater from the floodplain area due to the continuous recharge of fresh water from the Nile River through the irrigation conveying system.

Hydrochemical profiles (A-A', B-B', and C-C') for the major cations $\left(\mathrm{Ca}^{2+}, \mathrm{Mg}^{2+}, \mathrm{Na}^{+}, \mathrm{K}^{+}\right)$and anions $\left(\mathrm{HCO}_{3}^{-}\right.$, $\mathrm{SO}_{4}{ }^{2-}$, and $\mathrm{Cl}^{-}$) were constructed (Figure 7) and selected in different directions and locations (Figure 1) to give a hydrochemical view for the ions distribution in the study area. The irregularly change which detected along the hydrochemical profiles may be related to the geochemical change of groundwater along these directions due to local hydrogeological circumstances and the change of the mineral composition of sediments and soils. They also show that:

1- The floodplain area and the desert fringes characterized by $\mathrm{Na}-\mathrm{HCO}_{3}-\mathrm{SO}_{4}$ and $\mathrm{Na}-\mathrm{Cl}-\mathrm{SO}_{4}$ facies respectively.

2- Ions concentration increase toward the desert fringes areas.

2- Presence high concentration of sodium, chloride and sulphate ions indicate the dominant salts, in the studied area, are sodium chloride and sodium sulphate. 


\subsection{Hypothetical Salt Assemblages and Groundwater Genesis}

The hypothetical salt combination of the groundwater samples revealed the presence of different groups of salt assemblages (Table 2). The hypothetical salt combination revealed the presence of different salts arranged in terms of their predominant as $\mathrm{NaCl}, \mathrm{Na}_{2} \mathrm{SO}_{4}, \mathrm{NaHCO}_{3}, \mathrm{Mg}\left(\mathrm{HCO}_{3}\right)_{2}, \mathrm{Ca}\left(\mathrm{HCO}_{3}\right)_{2}, \mathrm{MgSO}_{4}$, and $\mathrm{KCL}$ and where the average of equivalent percentage is $39.9 \%, 29.16 \%, 11.73 \%, 11.1 \%, 8.9 \%, 3.98 \%$, and $1.73 \%$ respectively.

Table 2. Hypothetical salt combination of the groundwater samples

\begin{tabular}{|c|c|c|}
\hline Salt assemblages & Sample No. & Total samples \\
\hline $\mathrm{NaCl}>\mathrm{Na}_{2} \mathrm{SO}_{4}>\mathrm{Mg}\left(\mathrm{HCO}_{3}\right)_{2}$ & $1,2,9,10,11,12,15,16,17,18,25,28,29,30,31$ & 15 \\
\hline $\mathrm{NaHCO}_{3}>\mathrm{Na}_{2} \mathrm{SO}_{4}>\mathrm{NaCl}$ & $4,5,6,13$ & 4 \\
\hline $\mathrm{NaCl}>\mathrm{Na}_{2} \mathrm{SO}_{4}>\mathrm{NaHCO}_{3}$ & 3,19 & 2 \\
\hline $\mathrm{NaCl}>\mathrm{Na}_{2} \mathrm{SO}_{4}>\mathrm{Ca}\left(\mathrm{HCO}_{3}\right)_{2}$ & $20,21,23,24,26,27$ & 6 \\
\hline $\mathrm{NaCl}>\mathrm{Na}_{2} \mathrm{SO}_{4}>\mathrm{MgSO}_{4}$ & 14,22 & 2 \\
\hline others & 7,8 & 2 \\
\hline
\end{tabular}

The hydrochemical parameters $\left(\mathrm{rK} / \mathrm{rCl}, \mathrm{rNa} / \mathrm{rCl}, \mathrm{rMg} / \mathrm{rCl}, \mathrm{rCa} / \mathrm{rCl}\right.$, and $\mathrm{rSO}_{4} / \mathrm{rCl}$ ) are useful in comparing water from different sources and to define its genesis. The standard values for sea water according to these parameters (Ovchinnikov, 1955) with their minimum, and maximum values are summarized in Table 3. In the study area, all values are greater than the standard values indicating meteoric origin of the groundwater.

Table 3. Hydrochemical parameters of the groundwater samples in the study area

\begin{tabular}{cccc}
\hline Hydrochemical parameters & Minimum & Maximum & Standard values \\
\hline $\mathrm{rK} / \mathrm{rCl}$ & 0.0182 & 0.1598 & 0.0181 \\
$\mathrm{rNa} / \mathrm{rCl}$ & 1.4591 & 3.8518 & 0.8537 \\
$\mathrm{rMg} / \mathrm{rCl}$ & 0.2021 & 0.8583 & 0.1986 \\
$\mathrm{rCa} / \mathrm{rCl}$ & 0.1018 & 0.5602 & 0.0385 \\
$\mathrm{rSO}_{4} / \mathrm{rCl}$ & 0.4044 & 1.4135 & 0.103 \\
\hline
\end{tabular}

\section{Groundwater Quality}

\subsection{Groundwater Suitability for Drinking and Domestic Uses}

Assessment of groundwater quality for drinking purposes was evaluated by comparing the hydrochemical parameters of groundwater in the study area with the maximum acceptable concentration for drinking water according to (Table 4) the World Health Organization (2004), U.S. Environmental Protection Agency (2003), and the Egyptian standards for drinking water (EHCW, 1995).

Using the previous standards, it is concluded that:

(1) All the groundwater parameters, at the floodplain areas, are slightly below the maximum acceptable limits of the WHO, EPA, and EHCW standards (Figure 8), indicating its suitability for drinking.

(2) The majority of the groundwater under the desert fringes is suitable for drinking. 

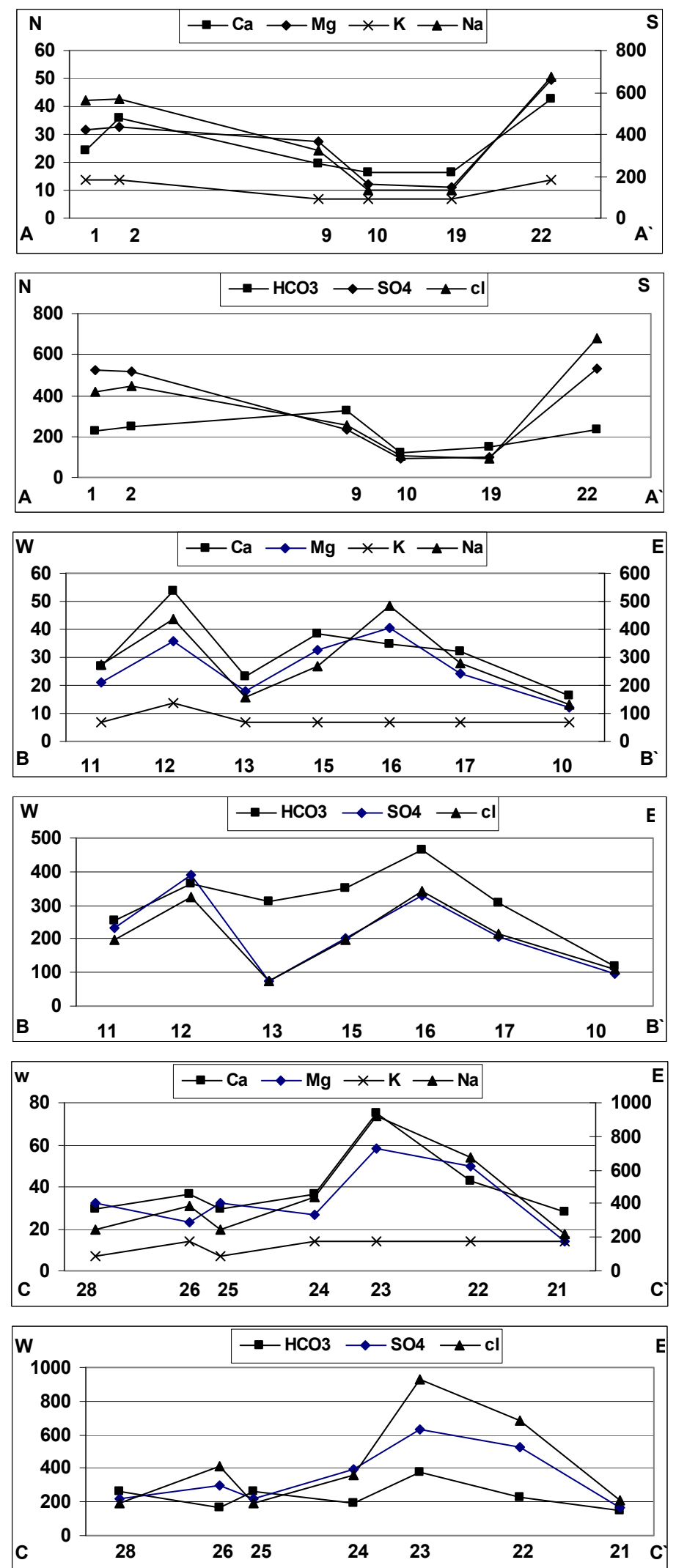

Figure 7. Hydrochemical profiles for the major cations $\left(\mathrm{Ca}^{2+}, \mathrm{Mg}^{2+}, \mathrm{Na}^{+}, \mathrm{K}^{+}\right)$and anions $\left(\mathrm{HCO}_{3}{ }^{-}, \mathrm{SO}_{4}{ }^{2-}\right.$, and $\left.\mathrm{Cl}^{-}\right)$: 1- A-A profile along the east part (N-S) 2- B-B' profile along the central part (W-E) 3- C-C' along the south part (W-E) of the study area 
According to the hardness degree, classified in terms of calcium carbonate concentration (Ayers et al., 1994), two water categories can be distinguished. The majority of water sampled from the floodplain area can be used for laundry purposes $(\mathrm{TH}<180 \mathrm{ppm})$. The second category is water with $\mathrm{TH}>180 \mathrm{ppm}$, that can't be used for domestic use. They include most of the wells of the desert fringes area.

\subsection{Groundwater Suitability for Irrigation Purposes}

According to the Sodium Adsorption Ratio (the US salinity laboratory staff, 1954), the SAR values of the Quaternary aquifer show that all of the groundwater sampled from the floodplain areas are excellent indicating its suitability for irrigation and can be used for all soil types. Under the desert fringes and new reclaimed areas, the SAR values show that about $10 \%$ of the water samples are excellent, $59 \%$ are good, and $9 \%$ are fair.

These results indicate that the majority of the groundwater under the desert fringes and new reclaimed areas is good can be used for irrigation recommended of sandy soils with good permeability. The other groundwaters are slightly unsuitable and can be used for soils with adequate drainage, special management and using plants with good salt tolerance.

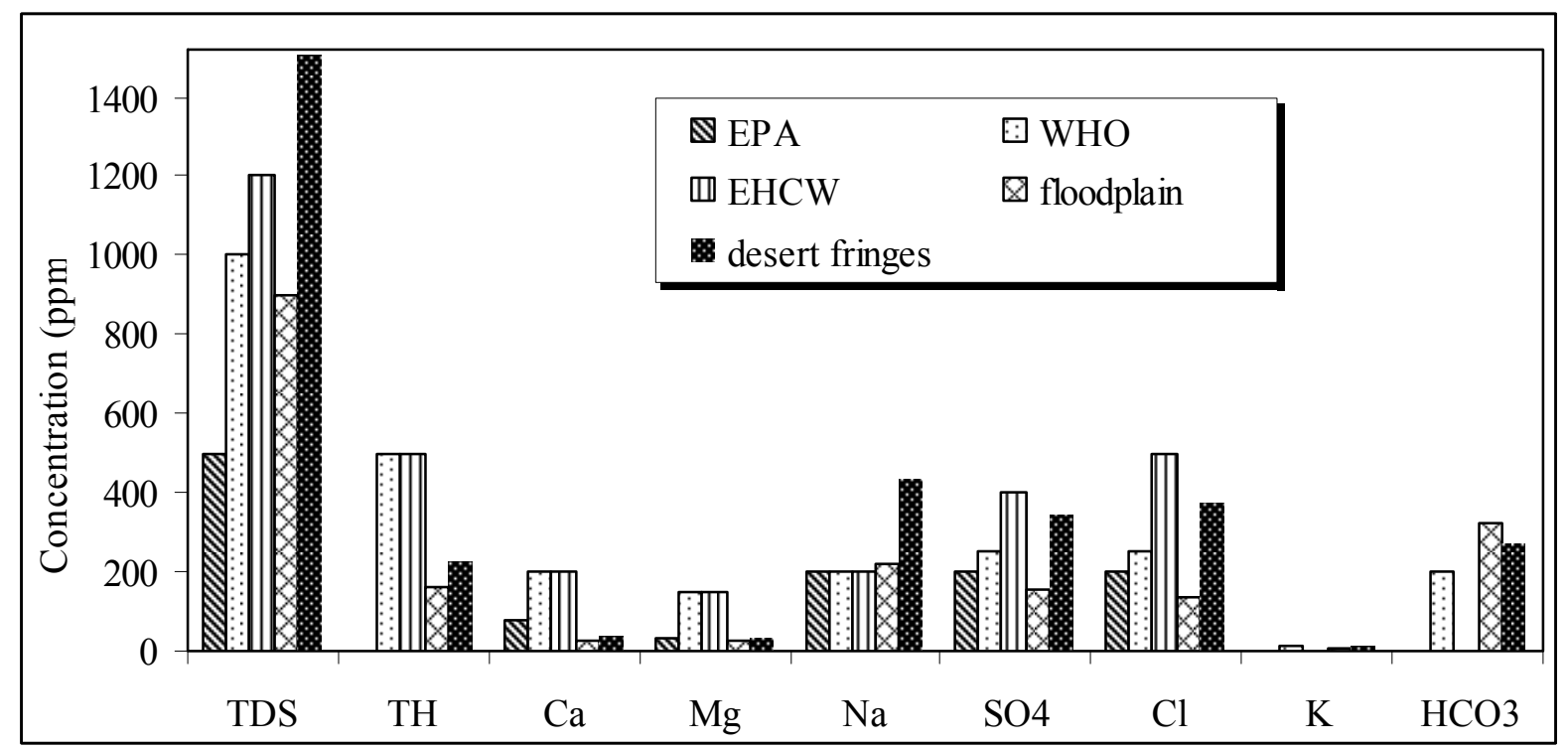

Figure 8. Ion concentrations in the groundwater samples with the WHO, EPA, and EHCW standards

Table 4. The maximum acceptable concentration for drinking water according to the WHO, EPA, and EHCW standards

\begin{tabular}{|c|c|c|c|c|c|c|}
\hline Constituent & Unit & $\begin{array}{l}\text { maximum } \\
\text { acceptable or } \\
\text { range of WHO }\end{array}$ & $\begin{array}{l}\text { maximum } \\
\text { acceptable or } \\
\text { range of EPA }\end{array}$ & $\begin{array}{l}\text { maximum } \\
\text { acceptable or } \\
\text { range of } \mathrm{EHCW}\end{array}$ & $\begin{array}{l}\text { average of } \\
\text { floodplain } \\
\text { samples }\end{array}$ & $\begin{array}{l}\text { average of } \\
\text { desert } \\
\text { fringes } \\
\text { samples }\end{array}$ \\
\hline $\mathrm{pH}$ & ----- & $6.5-8.5$ & $6.9-9.2$ & $6.5-9.2$ & $6.75-7.78$ & $6.5-7.8$ \\
\hline TDS & ppm & 1000 & 550 & 1200 & 896 & 1510 \\
\hline $\mathrm{TH}$ & $\begin{array}{l}\mathrm{mg} / \mathrm{L} \\
\mathrm{CaCO}_{3}\end{array}$ & 500 & ----- & 500 & 163 & 225 \\
\hline $\mathrm{Na}$ & ppm & 200 & 200 & 200 & 220 & 433 \\
\hline $\mathrm{SO}_{4}$ & ppm & 250 & 250 & 400 & 157 & 345 \\
\hline $\mathrm{Cl}$ & ppm & 250 & 250 & 500 & 134 & 376 \\
\hline $\mathrm{Ca}$ & ppm & 200 & 75 & 200 & 27 & 38 \\
\hline $\mathrm{Mg}$ & ppm & 150 & 30 & 150 & 23 & 32 \\
\hline
\end{tabular}




\section{Conclusion}

The Quaternary sediments represent the main aquifer in both the floodplain and the desert fringe areas and are made up of successive layers of fluvial sands and gravels with minor clay intercalations. In the floodplain area, the Quaternary aquifer is capped with the Neonile silt and fine-grained sand, which is replaced by the recent sediments $(\mathrm{Qw})$ in the desert fringes. Therefore, the aquifer system is under semi-confined condition in the floodplain, but it is under unconfined condition in the desert fringes. Water level values (range between 75.5 and $90 \mathrm{~m}$ a. m. s. 1.) decrease in the floodplain area and increase at the desert fringes, with groundwater flow from northeast to southwest. The depth to groundwater ranges from 5.0 (at the floodplain area) to $35 \mathrm{~m}$ (at the desert fringes area and reclaimed areas).

In general, all chemical constituents (TDS, TH, EC, major cations $\left(\mathrm{Ca}^{2+}, \mathrm{Mg}^{2+}, \mathrm{Na}^{+}\right.$, and $\mathrm{K}^{+}$), and major anions $\left(\mathrm{HCO}_{3}{ }^{-}, \mathrm{SO}_{4}{ }^{2-}\right.$, and $\left.\mathrm{Cl}^{-}\right)$have shown an increase under the desert fringes related to leaching processes of highly soluble minerals, which has high effect in the geochemistry of the groundwater in its flow path. The geochemical composition of groundwater indicates a direct relation between the lithology and relative abundance of ions. The floodplain area has low ions concentrations than desert fringes, due to the continuous recharge of fresh water from the Nile River through the irrigation conveying system. The chemical composition of the groundwater is dominated by sodium and bicarbonate at the floodplain area, while under the desert fringes $\mathrm{Na}^{+}$and $\mathrm{Cl}^{-}$are dominant. The hypothetical salt combination revealed the presence of different salts arranged in terms of their predominant as $\mathrm{NaCl}, \mathrm{Na}_{2} \mathrm{SO}_{4}, \mathrm{NaHCO}_{3}, \mathrm{Mg}\left(\mathrm{HCO}_{3}\right)_{2}, \mathrm{Ca}\left(\mathrm{HCO}_{3}\right)_{2}, \mathrm{MgSO}_{4}$, and $\mathrm{KCl}$ and where the average of equivalent percentage is $39.9 \%, 29.16 \%, 11.73 \%, 11.1 \%, 8.9 \%, 3.98 \%$, and $1.73 \%$ respectively. All the groundwater parameters at the floodplain and desert fringes areas are below than the maximum acceptable limits of the WHO, EPA, and EHCW standards, indicating its suitability for drinking and irrigation.

\section{References}

Abd El Razik, T. M. (1972). Comparitive studies on the Upper Cretaceous-Early Paleogene sediments on the Red Sea Coast, Nile Valley and Western Desert, Egypt (U.A.R.), Six Arab. Petroleum congress, Algiere, N.71 (B-3), pp. 1-23.

Ayers, R. S., \& Westcot, D. W. (1994). Water quality for agriculture FAO irrigation and Drainage paper 29, FAO. Rome, Italy.

Balachandar, D., Sundararaj, P., Rutharvel, M. K., \& Kumaraswamy, K. (2010). An investigation of groundwater quality and its suitability to irrigated agriculture in Coimbatore District, Tamil Nadu, India - A GIS approach. International Journal of Environmental Sciences, 1(2), 176-190.

CONOCO. (1987). Geological map of Egypt, NF 36 NW El Sad El Ali. Scale 1:500000. The Egyptian General Petroleum Corporation.Conoco Coral.

EHCW (Egyptian, Higher Committee of Water). (1995). Egyptian Standards for Drinking and Domestic Water According to the Act 27/1978 in Regulating of the Public Water Supplies. Egypt: Egyptian Governmental Press.

Hakim, M. A., Juraimi, A. S., Begum, M., Hasanuzzaman, M., Uddin, M. K., \& Islam, M. M. (2009). Suitability evaluation of groundwater for irrigation, drinking and industrial purposes. American Journal of Environmental Sciences, 5(3), 413-419. http://dx.doi.org/10.3844/ajessp.2009.413.419

Jain, C. K., Bandyopadhyay, A., \& Bhadra, A. (2010). Assessment of ground water quality for drinking purpose, District Nainital, Uttarakhand, India. Environ Monit Assess., 166, 663-676. http://dx.doi.org/10.1007/s10661-009-1031-5

Li, P., Wu, Q., \& Wu, J. (2011). Groundwater Suitability for Drinking and Agricultural Usage in Yinchuan Area, China. Inter. J. of Envir. Sci., 1(6), 1241-1249.

Mitra, B. K., Sasaki, C., Enari, K., \& Matsuyama, N. (2007). Suitability assessment of shallow groundwater for irrigation in Sand Dune area of Northwest Honshu Island, Japan. International Journal of Agricultural Research, 2(6), 518-527. http://dx.doi.org/10.3923/ijar.2007.518.527

Nagarajan, R., Rajmohan, N., Mahendran, U., \& Senthamilkumar, S. (2010). Evaluation of groundwater quality and its suitability for drinking and agricultural use in Thanjavur city, Tamil Nadu, India. Environ Monit Assess., 171, 289-308. http://dx.doi.org/10.1007/s10661-009-1279-9

Obiefuna, G. I., \& Sheriff, A. (2011). Assessment of Shallow Ground Water Quality of Pindiga Gombe Area, Yola Area, NE, Nigeria for Irrigation and Domestic Purposes. Research J. of Envir. and Earth Sciences, $3(2), 131-141$. 
Ovchinnikov, A. M. (1955). General Hydrogeology. Moscow, USSR.

Rashed, M., Idris, Y., \& Shaban, M. (2006). Integrative approach of GIS and remote sensing to represent the hydrogeological and hydrochemical conditions of Wadi Qena-Egypt .The $2^{\text {nd }}$ International Conf. on Water Resources \& Arid Environment. pp 1-9.

Said. R. (1962). The Geology of Egypt (p. 337). New York: Elsevier pub. Co., Amesterdam,

Said. R. (1981). The Geological Evolution of the River Nile (p. 151). Springer - Verlag. New York Inc.

Said. R. (1990). The Geology of Egypt (p. 751). Egyptian General Hurghada Inc. and Rep. of Exploration, S. A., Balkema, Rotterdam, Brookfield.

Sandford, K. S. (1934). Paleolithic man and the Nile Valley in Upper and Lower Egypt (1-131). Univ. Chicago Orient. Inst. Pub.

Selim, S. A. (2009). Hydrogeochemical assessment of the groundwater the area between Wadi Qena and Wadi El-Mathula, Upper Egypt. Sci. J. Fac. Sci. Minuf univ., XXIII(Geology 2), 1-25.

U. S. Salinity Lab. (1954). Diagnosis and improvement of saline and alkali soils Dept. Agriculture Handbook (1-60) V. 60, Washington, D. C.

U.S. Environmental Protection Agency. (2003) National Interim Primary Drinking Water Regulations List of Drinking Water Contaminants and Their MCLs. Annual Report, 816-F-03-016.

World Health Organization (WHO). (2004). Guidelines for Drinking Water Quality, vol. 1 Recommendations ( $3^{\text {rd }}$ ed). WHO, Geneva. 